\title{
First report of two Mesocriconema (Nematoda: Criconematidae) species in mulberry trees in Costa Rica ${ }^{1}$
}

\author{
Walter Peraza-Padilla ${ }^{2}$
}

\section{RESUMO}

Primeiro registro de duas espécies de Mesocriconema (Nematoda: Criconematidae) em amoreira na Costa Rica

Amostras de solo foram coletadas da rizosfera de plantas de amora (Morus alba L.), em uma parcela de $1.000 \mathrm{~m}^{2}$, na Fazenda Experimental Santa Lucia, em Barva, Heredia, Costa Rica, em agosto de 2013. As plantas apresentaram sintomas de amarelecimento, declínio e pouco desenvolvimento. Espécimes de dois nematoides anelados foram coletados do solo e identificados como Mesocriconema sphaerocephalum (Taylor 1936) Loof 1989 e M. anastomoides (Maqbool \& Shahina 1985) Loof \& De Grisse 1989, com base na análise morfológica e morfométrica de fêmeas. Ambos os nematoides foram previamente encontrados na Costa Rica. Porém, este é o primeiro relato de nematoides da família Criconematidae associados à amoreira, o qual fornece informações adicionais sobre este fitoparasita.

PALAVRAS-CHAVE: Mesocriconema sphaerocephalum (Taylor 1936) Loof 1989; Mesocriconema anastomoides (Maqbool \& Shahina 1985) Loof \& De Grisse 1989; morfometria; nematoides anelados.

Mulberry is a native species from temperate zones of Asia, which has spread worldwide (Benavides et al. 1994). In Central America, particularly in Costa Rica, it is propagated by cutting plants directly.

Its foliage is used as fodder for cattle and goats (Rodríguez et al. 1994, González 1996) and it can reach 12 meters high, being adapted as a fast growing shrub, with vigorous leaf shoots (Ting-Zing et al. 1988). It also presents an excellent nutritional value, due to its high levels of protein (20-24\%) and digestibility (75-85\%) (Benavides 1995).

Costa Rica is endowed with a suitable climate for the cultivation of different crops, but there are constraints affecting its agriculture, such as diseases and plant pests, mainly nematodes.

The Criconematidae family is a taxonomy commonly known as ring nematodes, due to the

\section{ABSTRACT}

Soil samples were collected from the rhizosphere of mulberry (Morus alba L.) trees, in a $1,000 \mathrm{~m}^{2}$ plot, at the Experimental Farm Santa Lucia, in Barva, Heredia, Costa Rica, in August 2013. The plants showed symptoms of yellowing, declining and poor development. Specimens of two ring nematode were collected from the soil and identified as Mesocriconema sphaerocephalum (Taylor 1936) Loof 1989 and M. anastomoides (Maqbool \& Shahina 1985) Loof \& De Grisse 1989, based on the morphological and morphometrical analysis of females. Both nematodes have been previously found in Costa Rica. However, this is the first report of nematodes from the Criconematidae family associated to mulberry trees and it provides additional information on the distribution of this phytoparasite.

KEY-WORDS: Mesocriconema sphaerocephalum (Taylor 1936) Loof 1989; Mesocriconema anastomoides (Maqbool \& Shahina 1985) Loof \& De Grisse 1989; morphometry; ring nematodes.

transversal annulation of the cuticle. All species are plant parasites that can attack vegetable crops and fruit trees, with a cosmopolitan distribution.

This notable group of nematodes has been reported in coffee plantations in El Salvador (Raski \& Golden 1966); Citrus sp. in Morocco; Zea mays L. in Kenya; Brasica oleracea L., Allium porrum L. and Lactuca sativa L. in Madagascar (Luc 1970); apricot in the United States (Mckenry et al. 1990); peach and apple in Spain (Escuer \& Palomo 1991); vineyards in Italy (Coiro et al. 1991); avocado, mango and tamarind in Spain (Castillo \& Gómez 1993); Mussa sp. in Jordan (Yousef \& S'Jacob 1994); peach in Mexico (Luna-Guerrero et al. 2011); barley, wheat and sugar beet in the Slovak Republic (Šály 1976), among others.

In Costa Rica, there is evidence of its presence in various crops, forests and different types of 
vegetation (Tarjan 1971, López-Chaves 1980 and 1988, López-Chaves \& Azofeifa-Chacón 1980, López-Chaves \& Salazar-Figueroa 1987a, Arroyo et al. 2004, Wingching-Jones et al. 2008, Powers et al. 2011, Guzmán-Hernández et al. 2011).

This study aimed to report the presence of ring nematodes (Mesocriconema sphaerocephalum and M. anastomoides) in mulberry trees, in Costa Rica.

The isolation and identification of nematodes were performed in the Laboratory of Nematology of the Universidad Nacional de Costa Rica, in Heredia, Costa Rica. Nine soil samples, which were placed in sealed plastic bags and stored at $4^{\circ} \mathrm{C}$, before analysis, were collected from a $1,000 \mathrm{~m}^{2}$ plot, at the Experimental Farm Santa Lucia, in Barva $\left(10^{\circ} 01^{\prime} 34.40^{\prime \prime} \mathrm{N}, 84^{\circ} 06^{\prime} 49.60^{\prime \prime} \mathrm{W}\right.$, altitude of $1,220 \mathrm{~m}$, average rainfall of 2,693 $\mathrm{mm}$ per year and average temperature of $23^{\circ} \mathrm{C}$ ), Heredia, which belongs to the School of Agricultural Sciences of the Universidad Nacional de Costa Rica, in August 2013. The area had been previously planted with sorghum, which had showed symptoms of yellowing and poor development.

Nematodes were extracted from soil samples by flotation-centrifugation (Jenkins 1964), killed and fixed in hot $4 \%$ formaldehyde $\left(70^{\circ} \mathrm{C}\right)$. Subsequently, fifteen females from each species were infiltrated with glycerin, by using the Seinhorst's modified slow method (Seinhorst 1959 and 1962), and mounted on slides, for observation and preservation. All specimens were deposited in the Criconematid Collection, in the Laboratory of Nematology of the Universidad Nacional de Costa Rica.

Both species were morphologically and morphometrically identified by using data collected by Geraert (2010). All measurements were taken in micrometers $(\mu \mathrm{m})$ and in the format mean \pm S.D. (standard deviation range), using an Olympus BX50 microscope and a stage micrometer. Images of key morphological features were taken with a Nikon DS-Fil camera and edited with the aid of Photoshop CS4. The classification of nematodes was based on Siddiqi (2000).

Five years after planting, mulberry trees showed symptoms of yellowing, declining and poor development. These general symptoms are often difficult to distinguish, because they are associated to other root pathogens and soil fungi. So, it is important to make a nematode analysis to detect phytoparasites, as proved in this investigation.

The nematode isolation and identification revealed the presence of $M$. sphaerocephalum
(Taylor 1936) Loof 1989 and M. anastomoides (Maqbool \& Shahina 1985) Loof \& De Grisse 1989, which belong to the Criconematidae (Taylor 1936) family, associated to mulberry.

The classification of the two nematode species was based on Siddiqi (2000), as it follows:

Tylenchina Chitwood in Chitwood \& Chitwood 1950

Criconematina Sidiqui 1980

Criconematiodea Taylor 1936 (1914) (Geraert 1966)

Criconematidae Taylor 1936 (1914)

Criconematinae Taylor 1936 (1914)

Mesocriconema sphaerocephalum (Taylor 1936) Loof 1989

Mesocriconema anastomoides (Maqbool \& Shahina 1985) Loof \& De Grisse 1989

Mesocriconema species presents a cuticle with retrorse annuli, mean annular tickness of $4.7 \mu \mathrm{m}$, smooth uneven or crenated margins and no posterior appendages. Lateral field is often present, usually by anastomoses. The first head annulus is seldom separated and the second head annulus is usually wider than the first. Submedian lobes are present, rarely absent. Labial plates are present or absent. Open vulva and anterior vulva lip are ornamented in several species. The post-vulval body is usually short, with round or truncate terminus, seldom acute. Males have a lateral field with 4 lines. The bursa is usually well developed, with enclosing terminus, rarely narrow and short. The tail terminus is round to acute. Juveniles present smooth uneven or crenate annuli posterior margins, never with appendages, and with annuli in profile never drawn out posteriad (Geraert 2010).

The genus Mesocriconema is closely related to Criconemoides, but it differs by having an open vulva and a difference in the structure of the submedian lobes (Loof \& De Grisse 1989). It is not always easy to evaluate these differences and both genera are synonymized by Hunt et al. (2005). On the other hand, Geraert (2010) uses the genus Mesocriconema as proposed by Brzeski et al. (1998).

M. sphaerocephalum (Figure 1) has been documented in crops in Europe, America, Africa and Asia. It was reported from Hawaii (Jensen et al. 1959); Mauritius (Willians 1960); Guatemala, Hawaii, Austria, India, Kenya, Nigeria, USA(South Carolina), Netherlands and Venezuela (Raski \& Golden 1966, 
Crozzoli \& Lamberti 2001, Lugo et al. 2010); Congo (Coomans 1966); Iran (Kheiri 1972); South Africa (Van den Berg 1980); Japan (Toida \& Momota 1981); Tanzania (Bridge 1984); India (Muthukrishnan 1987); Iran (Barooti 1987); Costa Rica (López-Chaves \& Salazar-Figueroa 1987b); Eastern Sudan (Zeidan \& Geraert 1989); Spain (Sierra de Cazorla) (GómezBarcina et al. 1989); Italy (Bello et al. 1988, Coiro et al. 1991); Spain (Gómez-Barcina et al. 1991, Escuer \& Bello 1994); Cameroon (Sakwe \& Geraert 1993); Belgium (Bert et al. 2003); and Brazil (Rossi \& Camargo 2005), among others.

M. sphaerocephalum has a cuticular retrorse annuli with irregular margins. It's a small nematode, ventrally arcuate and characterized by the presence of a high number of anastomoses throughout the body, forming a zig-zag pattern. The anterior body end appears truncated, labial disc is low, submedian lobes and labial plates are small and not protruding. Stylet is robust (about $51.0 \mu \mathrm{m}$ ), knobs 8.0-12.0 present a concave or anchor shape (about $10 \mu \mathrm{m})$. Criconematid oesophagus is typical. The vulva is open, simple, with rounded lips, devoid of projections. Gonad is often recurved, sometimes even twice. The post-vulval part is rounded. The vagina is straight and the postvulval body part is short, with a rounded tail. Males were not found. All the principal morphometric values of the specimens are in agreement with the ranges described by Geraert (2010). The population of M. sphaerocephalum reported here has a similar morphometrics to the description made by Cordero et al. (2012).

Females were fixed in formaldehyde and mounted in dehydrated glycerine, and all measurements were expressed in $\mu \mathrm{m}$ and in the format mean \pm S.D. (standard deviation range), as it follows: $\mathrm{n}=15 ; \mathrm{L}=342.5 \pm 33.7$ (288.0-415.0); stylet length $=$ $51.2 \pm 10.1(31.0-70.0) ; \mathrm{a}=9.3 \pm 1.6(6.4-12.6)$;
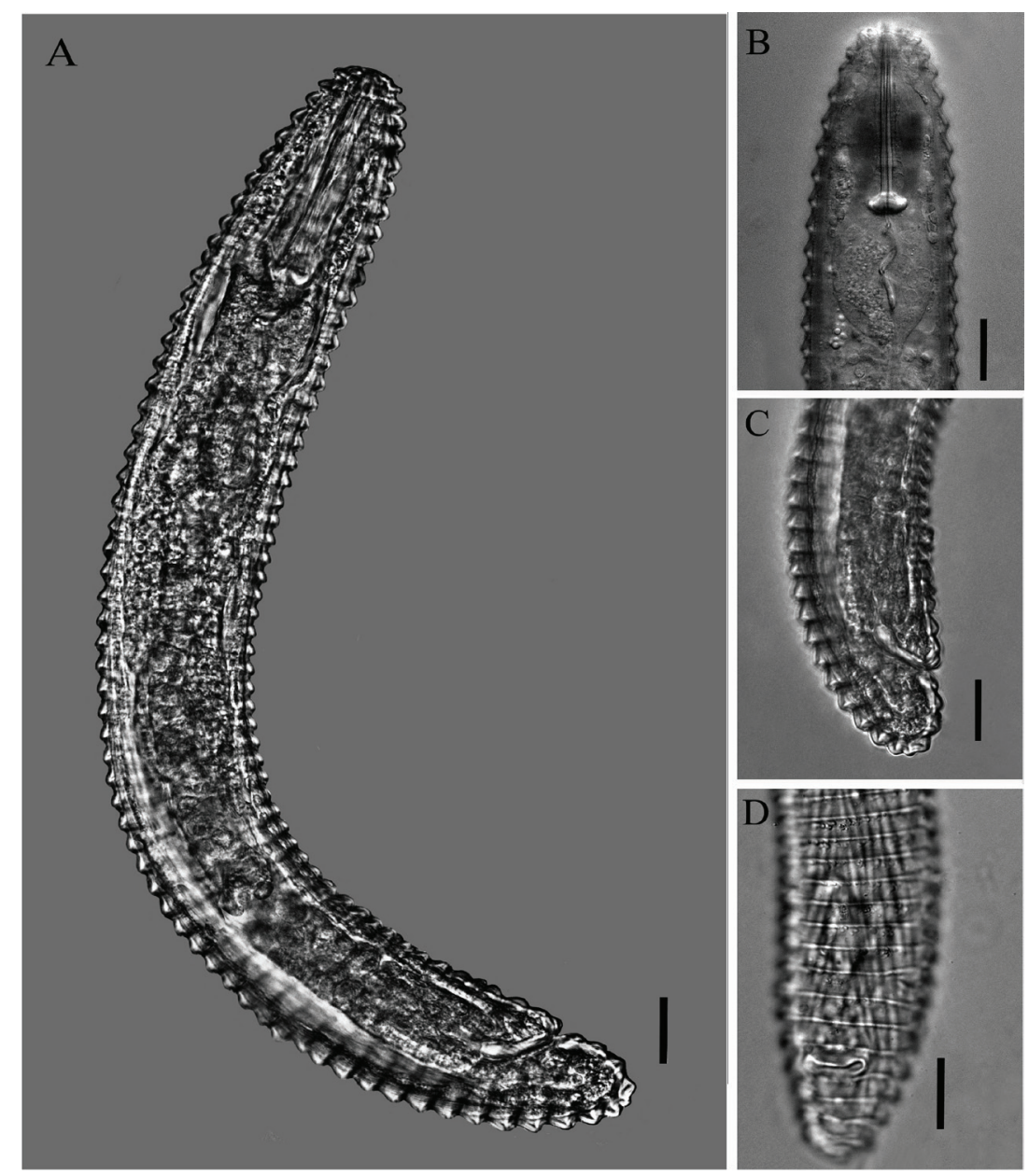

Figure 1. Micrographs of Mesocriconema sphaerocephalum (Heredia, Costa Rica, 2013). A: entire female body; B: anterior body portion showing stylet and submedian lobes; C and D: posterior portion showing vulva and tail shape. Scale bars $=20 \mu \mathrm{m}$. 
$\mathrm{b}=3.6 \pm 0.3(3.1-4.1) ; \mathrm{V} \%=92.0 \pm 2.4$ (84.5-94.2); first cephalic annulus diameter $=15.8 \pm 1.1$ (13.0-17.0); body annule width $=5.1 \pm 0.8$ (3.5-6.5); stylet knob width $=10.0 \pm 1.3(8.0-12.0)$; oesophagus length $=96.6 \pm 10.9$ (78.0-110.0); diameter at midbody $(\mathrm{MBW})=37.4 \pm 4.7$ (32.0-45.0); diameter at vulva $(\mathrm{VBW})=27.6 \pm 2.8(22.0-32.0)$; DEGO from stylet base $=4.7 \pm 1.3(3.0-9.0) ; \mathrm{R}=66.1 \pm 2.9$ (61.0-71.0); $\operatorname{Rex}=22.8 \pm 2.2(20.0-26.0) ; \mathrm{RV}=$ $4.9 \pm 0.8$ (4.0-7.0); $\mathrm{St} \% \mathrm{~L}=14.9 \pm 2.5$ (9.8-19.1); $\mathrm{St} \%$ Oes $=52.7 \pm 7.5$ (39.7-69.0); vulva length $(\mathrm{VL})=27.4 \pm 9.0(19.0-57.0) ; \mathrm{VL} / \mathrm{VBW}=0.9 \pm 0.2$ (0.7-1.2).

M. anastomoides (Figure 2) was first described in the Sargodha surroundings, in roots of Citrus sp. and pears (Pyrus comrnunis L.) from Naushera, Pakistan (Maqbool \& Shahina 1985, Loof \& De Grisse 1989). It belongs to the species of a separate Pakcriconemoides (Shahina \& Maqbool 1993) genus characterized by a small stylet with rounded knobs.
The species can be compared to M. microdorum and M. sphaerocephala.

$M$. anastomoides female nematodes are ventrally arcuate, bluntly rounded at both extremities, assuming a "C" shape. Body annuli is rounded anteriorly and more retrorse posteriorly, with irregular margins, slightly crenate towards the posterior region. Anastomoses of annuli are very prominent, forming a thick regular zig-zag structure distributed longitudinally over the body. Its head has two annuli, with the first one slightly anteriorly directed (10.0-11.0 $\mu \mathrm{m}$ wide) and the second one slightly thicker, retrorse and larger than the first annulus. The labial region is hemispherical, with four small but distinct submedian lobes. Pseudolips are irregular, with hexagonal labial disc, offset. Oral opening and amphid apertures are oval, on both lateral sides of the disc. Stylet is short and robust $(29.5 \mu \mathrm{m})$. Basal knobs are rounded ( $5 \mu \mathrm{m}$ wide), not projected forward, but distinctly sloping backward,
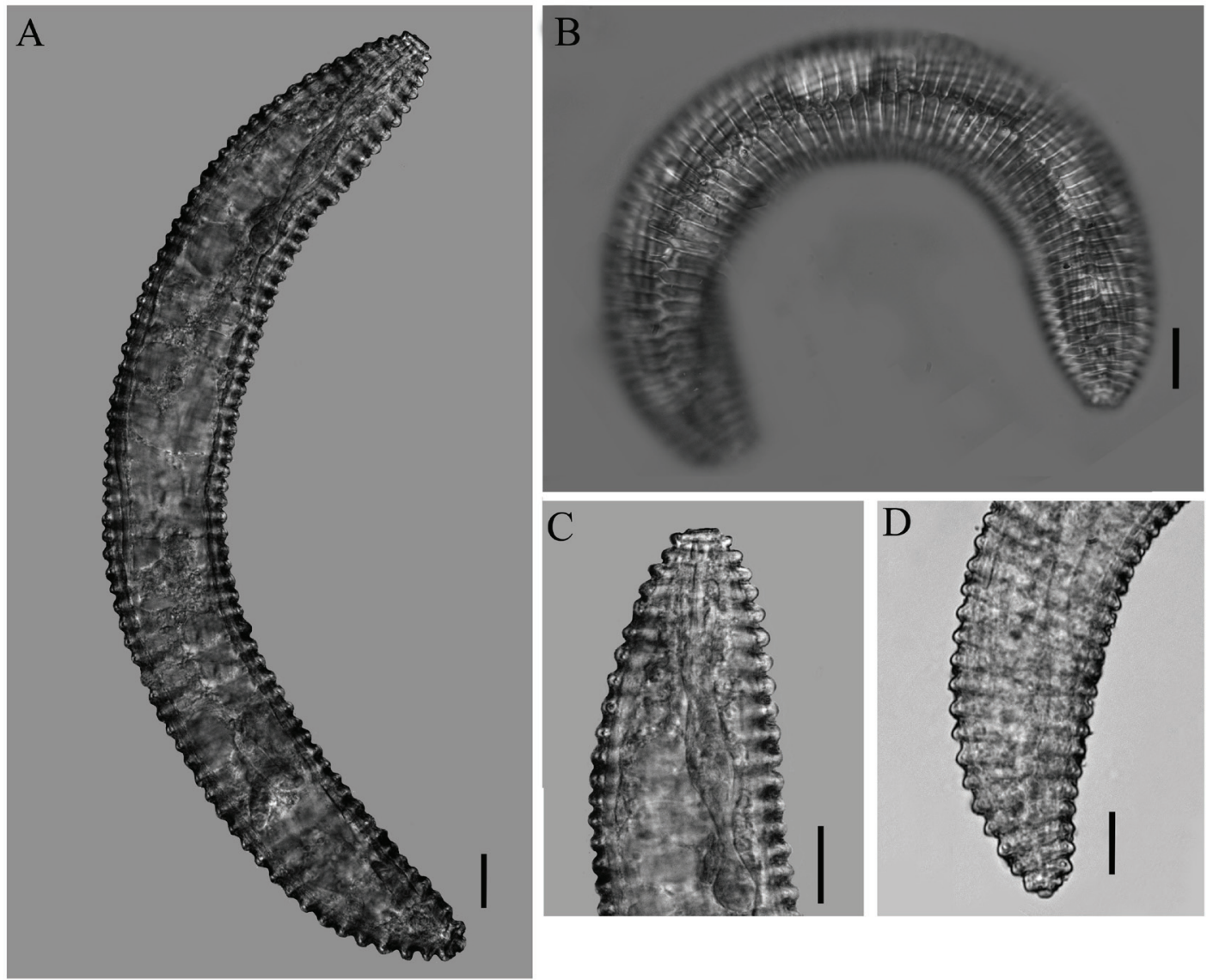

Figure 2. Micrographs of Mesocriconema anastomoides (Heredia, Costa Rica, 2013). A: entire female body; B: anastomosis of annuli very prominent, forming a thick zig-zag structure across all the body; C: anterior body portion; D: posterior body portion. Scale bars $=20 \mu \mathrm{m}$. 
and somewhat flattened at the base. Esophagus length is $76-79 \mu \mathrm{m}$ and the vulva is closed. The vagina is straight and the tail rounded, usually with 2-3 lobes on terminus. Males were not found. The population of $M$. anastomoides reported here has a similar morphometrics to the original description made by Maqboll \& Shahina (1985) and Loof \& De Grisse (1989).

Females were fixed in formaldehyde and mounted in dehydrated glycerine, and all measurements were expressed in $\mu \mathrm{m}$ and in the format mean \pm S.D. (standard deviation range), as it follows: $\mathrm{n}=15 ; \mathrm{L}=335.5 \pm 9.8(328.0-373.0)$; stylet length $=29.5 \pm 1.0(28.0-30.0) ; \mathrm{a}=8.7 \pm 1.1(7.3-9.6)$; $\mathrm{b}=4.5 \pm 0.2(4.0-4.7) ; \mathrm{V} \%=94.6 \pm 1.3(92.2-96.4)$; first cephalic annulus diameter $=10.3 \pm 1.0$ (10.0-11.0); body annule width $=4.2 \pm 0.7$ (4.0-5.5); stylet knob width $=5.0 \pm 0.0(5.0)$; oesophagus length $=77.0 \pm 1.4$ (76.0-79.0); diameter at midbody $(\mathrm{MBW})=40.0 \pm 3.6(37.0-44.0)$; diameter at vulva $(\mathrm{VBW})=22.0 \pm 1.4(20.0-24.0) ;$ DEGO from stylet base $=3.5 \pm 0.6(3.0-4.0) ; \mathrm{R}=67.5 \pm 1.3$ (66.0-69.0); Rex $=20.3 \pm 0.5$ (20.0-22.0); RV = $4.0 \pm 0.0$ (4.0); $\mathrm{St} \% \mathrm{~L}=8.5 \pm 0.5(7.8-9.0) ; \mathrm{St} \% \mathrm{Oes}=$ $38.3 \pm 1.2(36.8-39.5)$; vulva length $(\mathrm{VL})=23.3 \pm 4,6$ (20.0-30.0); VL/VBW $=0.9 \pm 0.1(0.8-1.0)$.

\section{ACKNOWLEDGEMENTS}

The author thanks Dr. Thomas O. Powers, from the University of Nebraska, Lincoln (USA), for the training on identification of criconematid species, during the spring and summer 2013.

\section{REFERENCES}

ARROYO, C. et al. Dinámica poblacional de nematodos fitoparásitos en Pejibaye (Bactris pasipaes K) para palmito. Agronomía Mesoamericana, San José, v. 15, n. 1, p. 53-59, 2004.

BAROOTI, S. A. List of plant parasitic nematodes of Iran. Tehran: Plant Pests and Diseases Research Institute, 1987.

BELLO, A.; COIRO, M. I.; REY, J. M. Criconematoidea sensu Siddiqui, 1980 en los viñedos del Trentino. Nematologia Mediterranea, Bari, v. 16, n. 1, p. 25-33, 1988.

BENAVIDES, J. Manejo y utilización de morera (Morus alba) como forraje. Agroforesterías en las Américas, San José, v. 7, n. 1, p. 1-7, 1995.
BENAVIDES, J.; LACHAUX, M.; FUENTES, M. Efecto de la aplicación de estiércol de cabra en el suelo sobre la calidad y producción de biomasa de morera (Morus sp). Árboles y Arbustos Forrajeros en América Central, San José, v. 11, n. 236, p. 495-514,1994.

BERT, W. et al. Tylenchomorpha (Nematoda: Tylenchina) in Belgium, an updated list. Nematology, Leiden, v. 5, n. 1, p. $435-440,2003$.

BRZESKI, M. W. et al. Morphological observations on three species of Mesocriconema Andrássy, 1962 [sic] and nomenclatorial note on M. goodeyi (Jairajpuri, 1963) Loof \& De Grisse, 1989 (Nematoda: Criconematidae). Journal of Nematode Morphology and Systematics, Jaén, v. 1, n. 1, p. 47-56, 1998.

BRIDGE, J. Coffee nematode survey of Tanzania: report on a visit to examine plant parasitic nematodes of coffee in Tanzania. St. Albans: International Institute of Parasitology, 1984.

CASTILLO, P.; GÓMEZ, B. A. Nematodos parásitos de las plantas asociados con cultivos tropicales y subtropicales en el sur de España. Nematologia Mediterranea, Bari, v. 21, n. 1, p. 45-47, 1993.

COIRO, M. I. et al. Criconematoidea in vineyards of Conegliano and Valdobbiadene, in the province of Treviso, Italy. Nematologia Mediterranea, Bari, v. 19, n. 1, p. 113119, 1991.

COOMANS, A. Some nematodes from Congo. Revue de Zoologie et de Botanique Africaine, Tervuren, v. 74, n. 1, p. 287-312, 1966.

CORDERO, M. A.; ROBBINS, R. T.; SZALANSKI, A. L. Taxonomic and molecular identification of Bakernema, Criconema, Hemicriconemoides, Ogma and Xenocriconemella species (Nematoda: Criconematidae). Journal of Nematology, College Park, v. 44, n. 4, p. 427446, 2012.

CROZZOLI, R.; LAMBERTI, F. Known and new species of Mesocriconema Andrássy, 1965 (Nematoda: Criconematidae) from Venezuela. Russian Journal of Nematology, Moscow, v. 9, n. 1, p. 85-105, 2001.

ESCUER, M.; BELLO, A. Nematodos del suelo de la familia Criconematidae en Cataluñia. Orsis, Barcelona, v. 9, n. 1, p. 59-75, 1994.

ESCUER, M.; PALOMO, A. Nematodos asociados a melocotoneros, perales y manzanos en el Bajo Cinca (Aragón). Orsis, Barcelona, v. 6, n. 1, p. 75-81, 1991.

GERAERT, E. Criconematidae of the world: identification of the family Criconematidae (Nematoda). Gent: Academia Press, 2010. 
GÓMEZ-BARCINA, A.; CASTILLO, P.; GONZÁLEZPAÍS, M. A. Nematodos fitoparásitos de la subfamilia Criconematinae Taylor, 1936 en la Sierra de Cazorla. Revista Iberoamericana de Parasitología, Santiago, v. 49, n. 3, p. 241-255, 1989.

GÓMEZ-BARCINA, A. et al. Morphometrics and SEM observations of four Criconematid species from Spain. Nematologia Mediterranea, Bari, v. 19, n. 1, p. 121-127, 1991.

GONZÁLEZ, J. Evaluación de la calidad nutricional de la morera fresca y ensilada con bovinos de engorde. 1996. 67 f. Tesis (Maestría) - CATIE, San José, 1996.

GUZMÁN-HERNÁNDEZ, T. de J. et al. Nematodos fitoparásitos asociados al arroz en las regiones Huetar Norte y Huetar Atlántica de Costa Rica. Agronomía Mesoamericana, San José, v. 22, n. 1, p. 21-28, 2011.

HUNT, D.; LUC, M.; MANZANILLA-LÓPEZ, R. Identification, morphology and biology of plant parasitic nematodes. In: LUC, M.; SIKORA, R. A.; BRIDGE, J. (Eds.). Plant parasitic nematodes in subtropical and tropical agriculture. Oxfordshire: CABI publishing, 2005. p. 11-52.

JENKINS, W. R. A rapid centrifugal-flotation technique for separating nematodes from soil. Plant Disease Reporter, Washington, D.C., v. 48, n. 1, p. 692, 1964.

JENSEN, H. J. et al. Nematodes associated with varietal yield decline of sugarcane in Hawaii. Plant Disease Reporter, Washington, D.C., v. 43, n. 1, p. 253-260, 1959.

KHEIRI, A. Plant parasitic nematodes (Tylenchida) from Iran. Biologisch Jaarboek Dodonaea, Gent, v. 40, n. 1, p. 224-239, 1972.

LOOF, P. A. A. Identification of criconematids. In: FORTUNER, R. (Ed.). Nematode identification and expert system technology. New York: Plenum Press, 1989. p. 139-152.

LOOF, P. A. A.; DE GRISSE, A. Taxonomic and nomenclatorial observations on the genus Criconemella De Grisse \& Loof, 1965, sensu Luc \& Raski, 1981. Mededelingen Faculteit Landbouwwetenschappen Rijksuniversiteit, Gent, v. 54, n. 1, p. 53-74, 1989.

LÓPEZ-CHAVES, R. Nuevas observaciones sobre la distribución espacial de nematodos parásitos del arroz (Oryza sativa L.) en Costa Rica. Turrialba, San José, v. 38, n. 1, p. 39-44, 1988.

LÓPEZ-CHAVES, R. Seasonal changes in the spatial distribution of nematodes in a fig plantation. Nematropica, Gainesville, v. 10, n. 1, p. 2, 1980.

LÓPEZ-CHAVES, R.; AZOFEIFA-CHACÓN, J. Nematodos fitoparásitos asociados con hortalizas en Costa Rica. Nematropica, Gainesville, v. 10, n. 1, p. 3, 1980.
LÓPEZ-CHAVES, R.; SALAZAR-FIGUEROA, L. Observaciones sobre la distribución espacial de nematodos fitoparásitos en árboles frutales. Agronomía Costarricense, San José, v. 11, n. 2, p. 141-147, 1987a.

LÓPEZ-CHAVES, R.; SALAZAR-FIGUEROA, L. Criconemella sphaerocephala (Nemata: Criconematidae) asociada a frutales en Costa Rica. Agronomía Costarricense, San José, v. 12, n. 1, p. 27-32, 1987 b.

LUC, M. Contribution à l'étude du genre Criconemoides Taylor, 1936 (Nematoda: Criconematidae). Cahiers ORSTOM, Dunkeque, v. 11, n. 1, p. 69-131, 1970.

LUGO, Z. et al. Nematodos fitoparásitos asociados a hortalizas en el Estado Falcón, Venezuela. Fitopatologia Venezolana, Maracay, v. 23, n. 1, p. 16-21, 2010.

LUNA-GUERRERO, A. Y. et al. Preliminary study of biotic and abiotic factors associated with peach tree death in Morelos, México. Nematropica, Gainesville, v. 41, n. 2, p. 254-262, 2011.

MAQBOLL, M. A.; SHAHINA, F. Criconemella anastamoides n. sp. (Nematoda: Criconematina) from Pakistan. Journal of Nematology, College Park, v. 17, n. 2, p. 236-239, 1985.

MCKENRY, M. V.; VINEROS, M.; TEVIOTDALE, B. Criconema mutabile associated with bacterial canker and Nemaguard rootstock. Plant Disease, St. Paul, v. 74, n. 5, p. 394, 1990.

MUTHUKRISHNAN, T. S. List of Criconematids recorded in South India. Indian Journal of Nematology, New Delhi, v. 17, n. 1, p. 37-45, 1987.

POWERS, T. et al. MOTUs: morphology, and biodiversity estimation: a case study using nematodes of the Suborder Criconematina and a conserved 18S DNA barcode. Journal of Nematology, College Park, v. 43, n. 1, p. 35-48, 2011.

RASKI, D. J.; GOLDEN, A. M. Studies on the genus Criconernoides Taylor, 1936 with descriptions of eleven new species and Bakernema variabile n.sp. (Criconematidae: Nematoda). Nematologica, Leiden, v. 11, n. 1, p. 501-565, 1966.

RODRÍGUEZ, C.; ARIAS, R.; QUIÑONES, J. Efecto de la frecuencia de poda y el nivel de fertilización nitrogenada, sobre el rendimiento y calidad de la biomasa de Morera (Morus sp.) en el trópico seco de Guatemala. Árboles y Arbustos Forrajeros en América Central, San José, v. 11, n. 236, p. 515-528, 1994.

ROSSI, C. E.; CAMARGO, B. F. L. C. Fitonematoides das superfamílias Criconematoidea e Dorylaimoidea associados a fruteiras de clima subtropical e temperado nos Estados de São Paulo e Minas Gerais. Nematologia Brasileira, Paracicaba, v. 29, n. 2, p. 183-192, 2005. 
SAKWE, P. N.; GERAERT, E. Criconematidae Taylor, 1936 (Nematoda) from Cameroon. Afro-Asian Journal of Nematology, Luton, v. 3, n. 1, p. 22-38, 1993.

ŠÁLY, A. Fauna of soil nematodes in the water work region Liptovská Mara. Acta Facultatis Rerum Naturalium Universitatis Comenianae Zoologia, Liptovská Mara, v. 20, n. 1, p. 5-21, 1976.

SEINHORST, J. W. A rapid method for the transfer of nematodes from fixative to anhydrous glycerin. Nematologica, Leiden, v. 4, n. 1, p. 67-69, 1959.

SEINHORST, J. W. On the killing, fixation, and transferring to glycerin of nematodes. Nematologica, Leiden, v. 8, n. 1, p. 29-32, 1962.

SHAHINA, F.; MAGHBOOL, M. A. Pakcriconemoides anastomoides (Maghbool and Shanina) gen. n., Criconemoides afghanicus sp. $\mathrm{n}$ and Macrosposthonia curvata alpine sub. sp. n (Nematoda: Criconematidae). Afro-Asian Journal of Nematology, Luton, v. 3, n. 1, p. 188-195, 1993.

SIDDIQI, M. R. Tylenchida parasites of plants and insects. Wallingford: CABI Publishing, 2000.

TARJAN, A. C. Some interesting associations of parasitic nematodes with cacao and coffee in Costa Rica. Nematropica, Gainesville, v. 1, n. 1, p. 5, 1971.

TAYLOR, A. L. The genera and species of the Criconematidae, a sub-family of the Anguillulinidae (Nematoda). Transactions of the American Microscopical Society, Lawrence, v. 55, n. 1, p. 391-421, 1936.
TING-ZING, Z. et al. Mulberry cultivation. Rome: FAO, 1998.

TOIDA, Y.; MOMOTA, Y. Criconematidae from mulberry fields in Japan. Japanese Journal of Nematology, Osaka, v. 13, n. 1, p. 14-19, 1981.

VAN DEN BERG, E. Studies on some Criconematidae (Nematoda) from South Africa with a description of Ogma rhombosquamatum (Mehta \& Raski 1971) Andrássy, Phytophylactica, Pretoria, v. 12, n. 1, p. 15-23,1980.

WILLIAMS, J. R. Studies on the nematode soil fauna of sugarcane fields in Mauritius: 4. Tylenchoidea (Partim). Mauritius: Mauritius Sugar Industry Research Institute, 1960.

WINGCHING-JONES, R. et al. Reconocimiento de nematodos en pastos tropicales en las comunidades de Sucre y San Vicente, Cantón de San Carlos. Agronomía Costarricense, San José, v. 32, n. 2, p. 129-136, 2008.

YOUSEF, D. M.; S'JACOB, J. J. A nematode survey of vegetable crops and some orchards in the Ghor of Jordan. Nematologia Mediterranea, Bari, v. 22, n. 1, p. 11-15, 1994.

ZEIDAN, A. B.; GERAERT, E. Plant parasitic nematodes from Sudan: Criconematidae, Tylenchulidae, Hoplolaimidae (Tylenchida). Mededelingen van de Faculteit Landbouwwtenschappen, Gent, v. 54, n. 1, p. 151-166, 1989. 